\title{
AZERBAIJAN-RUSSIA BORDERLINE SECURITY
}

\author{
Ekaterina V. Arkhipova \\ Volgograd State University, Volgograd, Russian Federation
}

\begin{abstract}
The Azerbaijan-Russia borderline mainly goes by the Caucasian mountain range and close to the Samur riverbed. Main border posts are situated close to the Caspian seashore while the locals living in the Upper Dagestan area have difficulties with crossing borderline. The locals are represented by the so called "divided peoples" whose living area was divided with the state border after 1991. The former inner borders ignored ethnic areas but now they became the lines crossing the ethnic groups of Legins, Avars, Tzakhurs and Rutuls. Certainly, those peoples are interested in specific rules for crossing the border. At the same time, their areas have not got the equipped border offices and they have to spend a lot of time and money for travelling to the neighboring districts via Baku or Vladikavkaz. Such problems arouse the radical demands among locals. The Lezgin movement for an independent Lezgistan is the most famous among them. Its supporters were involved in a terrorist attack in Baku in 1990-s and now they collect files about any problems connected with border issues, including the results of a demarcation process. They attract attention to the facts of all assignments made by Russian representatives. The activity of other ethnic groups was comparatively lower and they could make an agreement with local authorities about division of powers. Obviously, any solution about development of the border infrastructure may stabilize the separatism activity in the area.

The author determines the key challenges and threats to cross-border security at Azerbaijan-Russia borderline on the basis of analysis of Federal and regional media, declarations made by representatives of the local and borderline authorities, as well as online activities of national movements. The author reveals the infrastructure factors of ensuring cross-border activity, social and economic conditions of borderline districts development. The suggestion is made on the need to develop infrastructure borderline objects for complex development of the crossborder area that will allow preventing separatism.
\end{abstract}

Key words: borderline security, Caucasus, Azerbaijan, Russia, divided peoples, separatism.

УДК $327(5): 341.221 .27$

Дата поступления статьи: 14.10.2016

ББК 66.4(5Азе $), 9$ Дата принятия статьи: 16.01.2017

\section{ПОГРАНИЧНАЯ БЕЗОПАСНОСТЬ АЗЕРБАЙДЖАНО-РОССИЙСКОЙ ГРАНИЦЫ}

\author{
Екатерина Владимировна Архипова \\ Волгоградский государственный университет, г. Волгоград, Российская Федерация
}

\begin{abstract}
Аннотация. В статье на основе анализа информационных сообщений федеральных и региональных СМИ, заявлений представителей местной администрации и пограничных структур, онлайн-активности региональных национальных движений определяются основные вызовы и угрозы пограничной безопасности в зоне российско-азербайджанского пограничья. Автор определяет инфраструктурные факторы обеспечения пограничной и трансграничной активности, социально-экономические условия развития пограничных рай- онов. В статье высказывается предположение о необходимости развития инфраструктурных пограничных объектов для комплексного развития пограничного региона, что позволит избежать развития сепаратизма. ю Ключевые слова: пограничная безопасность, Кавказ, Азербайджан, Россия, разделенные народы, се푸 паратизм.
\end{abstract}


процесс делимитации не должен значительно затянуться. Однако к 2016 г. Российская Федерация еще не подписала договор о делимитации всех участков своей границы. Длительные переговоры часто затруднялись из-за территориальных споров, разделения населенных пунктов и мест хозяйственной деятельности, этнических особенностей приграничья. Не стал исключением и азербайджанский участок российской границы. Подписав договор о делимитации границы, стороны обязались решить давнюю проблему разделенных народов, хозяйственная деятельность которых осуществлялась на сопредельной территории, что требовало частого пересечения границы местными жителями, в то время как пограничная инфраструктура была к этому не готова. Установление пограничного контроля не могло не повлиять на социально-экономическое положение приграничных районов, что во многом определяет состояние пограничной безопасности на данном участке границы. Поэтому представляется важным определить влияние созданной пограничной инфраструктуры российско-азербайджанской границы на безопасность сопредельных территорий.

Российско-азербайджанская граница проходит по хребтам Большого Кавказа, во многом повторяет направление пограничной реки Самур и отклоняется от нее в ее дельте. Этот участок представляет собой естественный коридор, связывающий Российскую Федерацию с государствами Южного Кавказа транспортной сетью, проходящей вдоль побережья Каспийского моря. Будучи одним из трех коридоров, этот участок выделяется сравнительной развитостью своей инфраструктуры, так как представлен автомобильными путями, железной дорогой и трубопроводом Баку Новороссийск. В отличие от грузинского коридора эти пути не прерываются частично признанными государствами и позволяют относительно беспрепятственно, вне зависимости от погодных условий (как это бывает на осетинском участке российско-грузинской границы) осуществлять коммуникацию. В то же время этнический фактор создает специфические условия обеспечения пограничной безопасности.

Пограничная инфраструктура определена внутренними законодательными актами и межгосударственными соглашениями . В 1995 г. Азербайджаном и Россией было подписано соглашение «О пунктах пропуска через государственную границу между Российской Федерацией и Азербайджанской Республикой», которое определяло пункты пропуска: железнодорожный (Дербент (Россия) - Ялама (Азербайджан)); автомобильные: (ЯрагКазмаляр (Россия) - Самур (Азербайджан)), Тагиркент-Казмаляр (Россия) - Ханоба (Азербайджан)); для двустороннего сообщения с упрощенным порядком пересечения границы (Ново-Филя (Россия) - Ширвановка (Азербайджан), Чах-Чах (Россия) - Зухул (Азербайджан), Гарах (Россия) - Зухул (Азербайджан)). В ст. 3 оговаривалось, что «пересечение лицами границы в автомобильных пунктах пропуска может осуществляться с использованием транспортных средств или пешком» [24]. Учитывая хозяйственную особенность местных жителей, занимающихся отгонным скотоводством, ст. 6 предусматривала, что «места перегона скота определяются на основе взаимной договоренности между пограничными войсками и таможенными органами Российской Федерации с одной стороны и пограничными войсками и таможенными органами Азербайджанской Республики с другой стороны» [24]. Таким образом, документ устанавливал официальные пункты пропуска на всем участке границы, однако его главным недостатком было то, что он опирался на уже существовавшую транспортную инфраструктуру, которая была сосредоточена в приморской полосе. При этом жители Нагорного Южного Дагестана, которые еще в советские времена могли беспрепятственно пересекать когда-то административную границу по давно известным горным тропам, теперь для того чтобы официально навестить родственников на азербайджанской стороне, вынуждены делать крюк через приморскую зону до пунктов пропуска. Установленная пограничная линия мешала и осуществлению хозяйственной деятельности, поскольку в первое время ожидавшейся «взаимной договоренности» на государственном уровне достичь не удалось. Поэтому местные жители нелегально использовали устоявшиеся коридоры.

Итак, пограничные пункты пропуска сосредоточены вблизи дельты Самура, что ос- 
тавляет жителей Тляратинского, Рутульского, Ахтынского, Докузпаринского районов без возможности свободного перемещения. Сами районы являются изолированными от инфраструктуры Дагестана. Так, на сайте Тляратинского района отмечено: «Тляратинский муниципальный район входит в состав горной зоны Дагестана, является глубинным периферийным и труднодоступным районом Дагестана, имеет неблагоприятное транспортно-географическое положение по отношению к столичному центру - г. Махачкала и района является территориально изолированной и приграничной территорией РД». Сам район, который граничит и с Азербайджаном, и с Грузией, считается слабозаселенным, так в соответствии со статистикой, представленной административной властью района, плотность его населения составляет 17,6 чел./км ${ }^{2}$, в то время как в Дагестане в целом - 59,99 чел./км². При этом качество автомобильных дорог, связывающих район с республиканским центром, очень плохое, а дороги по направлению к азербайджанской границе просто нет. Таким образом, жители района оторваны и от границы, и от районного центра, а плотность приграничного населения ниже средней по республике, что вместе с экономическими проблемами региона может создавать предпосылки для развития сепаратизма.

Положение трансграничной инфраструктуры усугубляло и то, что традиционно поток пассажиро- и грузоперевозок на азербайджанском участке был высоким, а опытных пограничников и пограничной инфраструктуры здесь долго не было. Для упрощения процедуры пересечения границы в 1997 г. соседние страны подписали соглашение о взаимных безвизовых поездках граждан РФ и АР [25]. Антитеррористические кампании в Чечне, самопровозглашение государства Ичкерия, а также фактическая прозрачность российскоазербайджанской границы в нагорной части способствовали появлению сначала подозрений, а потом и фактов, подтверждающих, что боевики, принимавшие участие в военных действиях на Северном Кавказе, проходили лечение в азербайджанских и грузинских больницах, а Панкисское ущелье Грузии, не находящееся под контролем Тбилиси, стало местом отдыха для боевиков. Российские поли- тики в конце 1990-х гг. были убеждены, что именно дагестанский участок в период с 1991 по 1999 г. являлся тем коридором, через который в Чечню попадали наемники. Кстати, и отсутствие пограничного перехода в Нагорном Дагестане долгое время связывалось с антитеррористической операцией в Чечне. К слову, здесь в 1990-е гг. пограничники часто пресекали контрабанду оружия, обмундирования, медикаментов.

В дальнейшем уже и азербайджанские пограничники (Э. Гулиев), и дагестанские силовики (А. Черкесов) признавали, что поступающие из Ирана наркотики направляются через Азербайджан в Россию (в 2007 г. был особо отмечен в качестве коридора наркотрафика пост «Яраг-Казмаляр») [6]. Поэтому уже в 1999 г. премьер-министр РФ В.В. Путин заявил о необходимости введения визового режима между Россией и закавказскими республиками, а также ужесточения контроля за перемещением грузов на российско-азербайджанской границе [3]. Обращение азербайджанского президента к российскому, переговоры, а затем и визит В.В. Путина в Баку в 2001 г. позволили сторонам принять окончательное решение в пользу безвизового режима. Напомним, что в Баку в 2001 г. была подписана Бакинская декларация двух стран, дух и буква закона которых предполагали развитие сотрудничества, что возможно при благожелательном визовом режиме.

Однако еще долго финансовые проблемы стран, длительный процесс формирования пограничной инфраструктуры мешали создать условия для легализации всех пограничных пересечений границы с Азербайджаном со стороны местных жителей. В частности, как отмечали представители пограничной службы, именно в Тляратинском районе местным населением систематически нарушались правила перехода государственной границы.

Социально-экономические проблемы в пограничных государствах, национальная политика в Грузии привели к тому, что границу стало пересекать большое количество мигрантов (лезгины и аварцы) из северных районов Азербайджана и Грузии, а также контрабандисты [16; 19; 26].

Усиленное развитие пограничной инфраструктуры стало возможным только после 
2000-х годов. Необходимо было создать не только оборудованные пункты пропуска, которые уже сложились к тому времени, но и социальную инфраструктуру для пограничников, внедрить высокотехнологичные средства контроля и поиска на границе. В Рутульском районе в 2006 г. была открыта «самая отдаленная» пограничная застава «Джиных». На церемонии открытия присутствовал представитель азербайджанской стороны, начальник погрануправления А. Джабраилов, что говорит о высокой заинтересованности двух сторон в развитии сотрудничества в обеспечении пограничной безопасности. Службу на заставе на контрактной основе могут нести и местные жители, что снижает уровень безработицы в пограничных районах. Тогда же был поднят вопрос о строительстве упрощенного двустороннего перехода для жителей приграничных с Диндидагским перевалом районов [5]. Несмотря на то что проблема является актуальной для местных жителей еще с момента изменения статуса административной границы, как отмечалось чиновниками Дагестана на заседании Народного собрания в 2015 г., «за это время постановлений Правительства РД принято не было» [7]. Строительство горного погранперехода между Азербайджаном и Россией затруднялось и отсутствием необходимой дорожной инфраструктуры: из 70 км дороги между районным центром Рутул и границей в 2015 г. было построено только 8 км. Необходимость строительства такого погранперехода обусловлена отмеченными выше интересами местных жителей с обеих сторон границы: это районы, населенные разделенными народами ${ }^{1}$, и, для того чтобы пересечь границу по семейным обстоятельствам, им приходится ехать через погранпереходы в дельте реки Самур или через Владикавказ. А учитывая сложившуюся транспортную инфраструктуру, путь в азербайджанские северные провинции может пролегать и через Баку, что увеличивает продолжительность и стоимость визитов. На этом фоне в Дагестане получила развитие идея строительства Аваро-Кахетинской дороги, которая по замыслу должна связать Нагорный Дагестан с горными районами Грузии и позволит местным жителям сократить временные и финансовые расходы для посещения родственников на территории другого государства, придавая импульс экономическому развитию отдаленных приграничных районов. Однако сообщений о сотрудничестве с представителями соседних стран по этому вопросу до сих пор нет.

Негативная оценка Азербайджаном российских действий по укреплению границы была смягчена после визита В.В. Путина в Баку в начале 2001 года. Потепление в политических отношениях между странами сделало возможным развитие сотрудничества между погранведомствами двух стран. Так, в 2002 г. было подписано соглашение о деятельности приграничных представителей для ускоренного обмена информацией и развития сотрудничества по обеспечению пограничной безопасности. В сентябре 2002 г. было подписано соглашение между Российской Федерацией и Азербайджанской Республикой о разграничении сопредельных участков дна Каспийского моря, что существенно способствовало налаживанию доверительной атмосферы в российско-азербайджанских отношениях, в том числе по пограничным вопросам. Уже весной 2003 г. в Дагестане были проведены совместные учения пограничников России, Казахстана и Азербайджана. Надо отметить, что в сфере сотрудничества по обеспечению военной и пограничной безопасности Азербайджана России приходится конкурировать с Турцией $[20$, с. 26], поэтому следует положительно оценивать двустороннее стремление создать позитивные тенденции в таком болезненном вопросе, как пограничная безопасность. Можно сказать, что сотрудничество погранведомств двух стран развивалось в дальнейшем стабильно: проводились встречи, организовывался обмен информацией, силовики договорились о совместных действиях в случае незаконных пересечений границы $[1 ; 17 ; 22]$.

Однако еще долго политики и эксперты Азербайджана выражали недоверие по отношению к российским действиям. Так, уже в 2005 г. азербайджанский журналист и исследователь С. Расулзаде писал, что российская политика по укреплению пограничной инфраструктуры является попыткой создания военных баз, в перспективе имеющих возможности вести наступательные действия на территории Азербайджана [23]. Ведь за 1990-е гг. 
в азербайджанском истеблишменте сложилась устойчивая практика обвинений российских спецслужб в подстрекательстве жителей северных районов Азербайджана. Тогда основная радикальная масса местных жителей, преимущественно лезгин, объединилась в рамках национально-политического движения «Садвал», чьи требования включали: ликвидацию российско-азербайджанской границы, создание лезгинского национального государства. Им приписывают ряд нападений на азербайджанских пограничников, организацию теракта в Бакинском метро, столкновения с азербайджанской полицией. Учитывая, что Дербент в свою очередь населен другим разделенным народом - азербайджанцами, можно считать маловероятным нацеленность российских спецслужб на дестабилизацию пограничного пространства. Со временем радикальные требования смягчились и сводились к следующему: свободное пересечение границы и создание свободной экономической зоны «Самур» в приграничной территории, где проживают лезгины [15, с. 116].

А в связи с тем, что экономически депрессивные районы севера Азербайджана только на рубеже веков стали объектом внимания государственной политики, это позволило несколько улучшить их социально-экономическое развитие и снизить напряженность в российско-азербайджанских отношениях. Доказательством наличия определенного доверия в отношениях между спецслужбами можно считать тот факт, что в 2008 г. Россия, Азербайджан и Иран договорились о создании консорциума по строительству железной дороги Казвин - Решт - Астара (Иран - Азербайджан), где возможно соединение с РЖД [2]. Иран обещал завершить строительство в 2013 году.

Однако вопрос разделенных народов обострился в связи с подписанием российскоазербайджанского договора о делимитации государственной границы в 2010 году. 18 июня 2011 г. договор о делимитации вступил в силу. В ходе обсуждения стороны решали такие проблемы, как:

1. Раздел и отвод воды из реки Самур, необходимость создания пятикилометровой пограничной зоны, которую требовали российские и азербайджанские власти. Эта мера лишала местных жителей самых плодородных земель долины реки Самур в условиях малоземелья.

2. Отсутствие пограничной инфраструктуры, что вело к незаконным пересечениям границы жителей приграничья, а это в свою очередь давало основания для взаимных обвинений сторон в поддержке сепаратизма и террористов.

3. Разделенные народы. Эта проблема обострилась из-за необходимости решения вопроса о статусе жителей российских анклавов - преимущественно лезгин - на территории Азербайджана: Храх-Уба и Урьян-Уба. Как официально заявляли российские чиновники, местным жителям предложили сделать выбор: «либо получить гражданство Азербайджана по упрощенной схеме, либо сохранить гражданство России и встать на учет в миграционной службе, либо переселиться в Россию» [9]. Однако на последовавших митингах в Дагестане жители сел обратили внимание на то, что их права на выбор гражданства нарушались [11]. Возникали вопросы и по поводу организации продажи имущества на территории Азербайджана, и по поводу организации выезда из Азербайджана и размещения на территории России. Очевидно, что местным жителям было бы предпочтительнее сохранить статус-кво: проживание на территории с российским гражданством, но этот вариант не устраивал ни азербайджанские, ни российские власти. Трактовка событий, которую давали жители села Храх-Уба (лезгины) значительно отличалась от официальной российской и азербайджанской: они рассматривают эту территорию как «исконно свою», отмечают, что «политики отдали наши земли Азербайджану, теперь нас хотят сделать беженцами» [18]. Эта позиция оспаривалась азербайджанскими властями на том основании, что в советский период спорные территории были переданы во временное пользование малоземельным жителям Дагестана, таким образом оспаривая факт сложившегося проживания лезгин на территории Северного Азербайджана.

Решение территориального вопроса не в пользу лезгин спровоцировало рост политической активности федеральной национальнокультурной автономии лезгин. Ее интернетпортал с одноименным названием подробно 
освещает вопросы, связанные с переселением лезгин из Азербайджана в Россию, их журналисты внимательно следят за процессом делимитации и с еще большим вниманием за демаркацией границы, обращая внимание на те или иные территориальные уступки, которые совершали российские представители [14; 27]. Впрочем, для работы любой демаркационной комиссии территориальные обмены являются нормой, потому что определение границы на местности должно учитывать ландшафтные особенности и хозяйственную деятельность приграничных жителей. Кроме того, следует отметить активность движения «Свободный Лезгистан», которое также представлено в сети Интернет [10]. Его активисты на страницах портала обсуждали и освещали положение лезгин в Азербайджане до подписания договора 2010 г., а затем и политические меры, предпринятые лезгинами по донесению своего мнения до глав государств, а в настоящее время раскрывают процесс переселения лезгин в Российскую Федерацию. Оценки, которые даются здесь, можно назвать более жесткими, так как лезгин считают «ненужными». На самом деле, проблема положения лезгин в РФ возникла с момента подписания договора о делимитации: они в течении длительного времени не могли получить ответ от российских властей, куда можно переселиться из Азербайджана. С 2012 г. им разрешили переезд в Дагестан. Все же данное решение не помогло снизить накал страстей вокруг пограничной тематики, и можно предположить, что именно эта проблема стала мобилизующим фактором в развитии национального лезгинского движения.

Отдельно нужно рассмотреть процедуру пересечения границы как возможности осуществления трансграничной кооперации. Если до 2005 г. местные жители часто использовали внутренний паспорт для пересечения границы, то после 2005 г. пропуск и российскими, и азербайджанскими пограничниками стал осуществляться только по заграничному паспорту. Это вызвало временное сокращение легального потока, так как местные жители вынуждены были получать паспорт, для чего нужно было заплатить пошлину, на которую не всегда были деньги. Жители горных районов зачастую не имели даже внутреннего пас- порта нового, несоветского, образца для получения заграничного паспорта. Таким образом, местные жители сталкивались с юридическими и инфраструктурными препятствиями при пересечении границы.

Россия неоднократно в одностороннем порядке вводила ограничения на пересечение границы. Так, в сентябре 2004 г. в связи с проведением антитеррористической кампании азербайджано-российская граница была закрыта для всех автотранспортных средств. С 2010 г. на пунктах пропуска «Яраг-Казмаляр» и «Тагиркент-Казмаляр» действует только автомобильное сообщение. Сложившаяся практика существенно затрудняет пересечение границы местными жителями, которым приходится за определенную плату «подсаживаться» к водителям, что создает угрозы личной безопасности пассажиров и водителей, а также угрозы пограничной безопасности.

В апреле 2010 г. Народное собрание Дагестана обратилось к В. Путину с просьбой реконструировать пункты пропуска. Работы по обеспечению пешеходного перехода начались с осени 2011 года [12]. Однако до 2016 г. путешественники, пересекающие границу, отмечают плохое состояние моста через реку Самур, в то время как сами погранпереходы постепенно модернизируются.

Серьезные затруднения, созданные при пересечении границы местными жителями, стали предпосылкой для расцвета коррупции на российской-азербайджанской границе. О фактах вымогательства денег сообщали и граждане РФ, следующие в Азербайджан, и граждане Азербайджана, следующие в РФ. Этого же не отрицали и местные чиновники. Так, в работе К. Казенина, М. Сулейманова, М. Алексеева описаны факты коррупции: «На этом участке границы делаются большие деньги. Мост между Азербайджаном и Дагестаном называется “золотым” из-за вымогательств. По словам чиновника из Кусарского района Магомеда Велибекова, необходимость в заграничных паспортах только увеличит коррупцию» [13]. В работе описаны случаи мздоимства пограничников и полиции по отношению к автомобилям с номерами соседнего государства. Из-за этого сокращается трансграничный товарооборот. Азербайджанские интернет-порталы наполнены впечатлениями 
граждан Азербайджана от коррупции российских пограничников и таможенников: «Но больше всего поражала наглость, с которой они вымогали деньги у пассажиров. “Давай хормет. 200 рублей”, - стали требовать они с пассажиров-мужчин. Практически все пассажиры предпочли безропотно расстаться с 200 рублями. Несговорчивых же проверяющие приглашали в купе проводника, откуда несчастные возвращались с таким унылом видом, что становилось понятно: "хормет” сделать все же пришлось». В то же время их отзывы про азербайджанских пограничников были только положительными: «Таможенники так же скрупулезно проверяли багаж. Каких-либо эксцессов или проблем в нашем вагоне не было. Никто не требовал от нас денег, это уже удивляло» [4]. Важно отметить, что после 2015 г. количество жалоб на нарушение прав граждан, пересекающих границы, существенно сократилось [21]. Стороны осуществили модернизацию погранпереходов, оборудовали их системой видеонаблюдения, что значительно сокращает возможности для нарушений. В то же время возросло количество сообщений о временном закрытии того или иного пункта пропуска, что связано с техническими или природными причинами. Сам факт появления таких сообщений говорит о том, что с помощью сети Интернет местные погранслужбы стремятся регулировать трансграничный поток и в случае необходимости перенаправлять путешественников на другие пункты пропуска. Благоприятным условием стало введение с 2016 г. в действие договора между Азербайджаном и Россией по системе автомобильного страхования Green Card. Теперь Азербайджан признает российский полис ОСАГО, а РФ признает Green Card, выданный на территории Азербайджана. Однако в 2014 г. Азербайджан ввел ограничения на ввоз в страну автомобиля ниже стандарта Евро-4. Водитель при въезде должен оставить «гарантийную сумму», которая достигает $40 \%$ стоимости транспортного средства и которую при выезде ему должны вернуть [8]. Вызывает сомнения, что жители приграничных районов могут себе позволить пересекать границу со свободной суммой, покрывающей этот «залог». Кроме того, здесь возможны ущемления прав въезжающих при расчете кросс-курсов валют.
На форумах посетители отмечают затруднения при возвращении «залога».

Таким образом, «на месте», то есть в приграничных районах, у жителей существует настоятельная потребность в развитии приграничной инфраструктуры. Однако правительства и России, и Азербайджана, опасаясь за целостность своих стран, пытаются контролировать все трансграничные потоки и при развитии приграничной инфраструктуры в первую очередь заботятся о пограничной безопасности. В результате население начинает прибегать к нелегальным возможностям пересечения границы, что существенно снижает эффективность правительственных мер. Несмотря на это, положительная динамика российско-азербайджанских отношений и развитие пограничной инфраструктуры могут позволить снизить негативное влияние пограничных вызовов.

\section{ПРИМЕЧАНИЕ}

${ }^{1}$ В эту группу относят этносы, проживавшие по разные стороны административной границы между РСФСР и АзССР. После 1991 г. их места расселения разделила государственная граница. На российско-азербайджанском участке к ним относят: цахур, аварцев, рутульцев и лезгин.

\section{СПИСОК ЛИТЕРАТУРЫ}

1. Азербайджан усилил охрану границы с Россией // Кавказский узел. - Электрон. текстовые дан. - Режим доступа: http://www.kavkaz-uzel.ru/ articles/70768/ (дата обращения: 13.05.2016). - Загл. с экрана.

2. Азербайджан, РФ и Иран подписали ряд документов в рамках создания транспортного коридоpa Север-Юг // Кавказский узел. - Электрон. текстовые дан. - Режим доступа: http://www.kavkaz-uzel.ru/ articles/180744/ (дата обращения: 13.05.2016). - Загл. с экрана.

3. Алиев просит Ельцина не вводить визовый режим // Независимая газета. - Электрон. текстовые дан. - Режим доступа: http://www.ng.ru/cis/199911-19/5_aliev.html (дата обращения: 28.09.2016). Загл. с экрана.

4. Батыев, Б. Семь кругов ада на российско-азербайджанской границе / Б. Батыев // Vesti.az. - Электрон. текстовые дан. - Режим доступа: http://www. vesti.az/news/46640 (дата обращения: 03.10.2016). Загл. с экрана. 
5. В Дагестане сданы еще две заставы // Kunak Inform. - Электрон. текстовые дан. - Режим доступа: http://ikunak.ru/news/2006/10/11/22338 (дата обращения: 28.09.2016). - Загл. с экрана.

6. В столкновениях с наркоконтрабандистами погибло 7, ранено 9 пограничников // Новости Азербайджан. - Электрон. текстовые дан. - Режим доступа: http://www.newsazerbaijan.ru/obsh/20111124/ 6622694.html (дата обращения: 28.09.2016). - Загл. с экрана.

7. Вопросы создания пунктов пропуска на российской границе обсудили в Народном собрании // Республиканское информационное агентство. - Электрон. текстовые дан. - Режим доступа: http://www.riadagestan.ru/mobile/news/politics/ voprosy_sozdaniya_punktov_propuska_na rossiyskoy_granitse_obsudili_v_narodnom_sobranii/ (дата обращения: 28.09.2016). - Загл. с экрана.

8. Вступают в силу новые правила въезда в страну на автомобилях // Disput.az. - Электрон. текстовые дан. - Режим доступа: http://www.disput.az /index.php?app=forums\&module $=$ forums \& controller =topic\&id=637173 (дата обращения: 03.10.2016). Загл. с экрана.

9. Гражданам России в Азербайджане предложили выбор: легализуйтесь, либо уезжайте // НИРА «Аксакал». - Электрон. текстовые дан. Режим доступа: http://aksakal.info/news-cis/19856grazhdanam-rossii-v-azerbaydzhane-predlozhilivybor-legalizuytes-libo-uezzhayte.html (дата обращения: 29.07.2011). - Загл. с экрана.

10. Движение «Свободный Лезгистан». - Электрон. текстовые дан. - Режим доступа: http: //lezgistan.tv (дата обращения: 03.10.2016). - Загл. с экрана.

11. Ионов, О. Жители села Храх-уба проведут в столице Дагестана новую акцию протеста / О. Ионов // Кавказский узел. - Электрон. текстовые дан. - Режим доступа: http://www.kavkaz-uzel.ru /articles/185655/ (дата обращения: 03.10.2016). - Загл. с экрана.

12. Ионов, О. Росграница: пограничные пункты между Дагестаном и Азербайджаном будуг оборудованы пешеходными дорожками / О. Ионов // Кавказский узел. - Электрон. текстовые дан. - Режим доступа: http://www.kavkaz-uzel.ru/articles/196368/ (дата обращения: 03.10.2016). - Загл. с экрана.

13. Казенин, К. Дагестанские народы Азербайджана. Политика, история, культура / К. Казенин, М. Сулейманов, М. Алексеев. - М. : Европа, 2006. Электрон. текстовые дан. - Режим доступа: http:// www.redov.ru/politika/dagestanskie_narody_ azerbaidzhana_politika_istorija_kultura/index.php (дата обращения: 29.09.2016). - Загл. с экрана.

14. Куда девались земли южной границы Дагестана? // Федеральная лезгинская национально- культурная автономия. - Электрон. текстовые дан. Режим доступа: http://flnka.ru/digest-analytics/3319kuda-devalis-zemli-yuzhnoy-granicy-dagestana.html (дата обращения: 03.10.2016). - Загл. с экрана.

15. Литвинова, Т. Н. Национально-культурная автономия как форма самоопределения и политического участия народов России (на примере лезгин) / Т. Н. Литвинова // Исторические, философские, политические и юридические науки, культурология и искусствоведение. Вопросы теории и практики. - 2012. - № 7 (21), ч. III. - С. 115-118.

16. Меджид, Ф. В Азербайджане выявлена крупная партия контрабанды / Ф. Меджид // Кавказский узел. - Электрон. текстовые дан. - Режим доступа: http://www.kavkaz-uzel.ru/articles/159584/ (дата обращения: 03.10.2016). - Загл. с экрана.

17. Меджид, Ф. Пограничники Азербайджана и России продолжат взаимодействие / Ф. Меджид // Кавказский узел. - Электрон. текстовые дан. - Режим доступа: http://www.kavkaz-uzel.ru/articles/144745/ (дата обращения: 03.10.2016). - Загл. с экрана.

18. Митинг храхцев: «Храх-Уба-территория России» // Движение «Свободный Лезгистан». Электрон. текстовые дан. - Режим доступа: http:// www.lnka72.ru/Newsm/758-Miting-khrakhcev-1KHrakh-uba-territoriya-Rossiir (дата обращения: 03.10.2016). - Загл. с экрана.

19. На границе Азербайджана с Россией задержаны двое, пытавшихся перевезти в Россию героин // Кавказский узел. - Электрон. текстовые дан. - Режим доступа: http://www.kavkaz-uzel.ru/articles/80891 / (дата обращения: 03.10.2016). - Загл. с экрана.

20. Парубочая, Е. Ф. Сотрудничество Турции и Азербайджана в военной сфере на рубеже XXXXI веков / Е. Ф. Парубочая // Вестник Волгоградского государственного университета. Серия 4, История. Регионоведение. Международные отношения. - 2015. - № 6 (36). - С. 24 - 37. - DOI: http: //dx.doi.org/10.15688/jvolsu4.2015.6.3.

21. Пересечение на автомобиле границы Азербайджан - Россия // Форум Woman-az.ru. - Электрон. текстовые дан. - Режим доступа: http://woman-az.ru/ viewtopic.php?t=360 (дата обращения: 29.09.2016). Загл. с экрана.

22. Расулзаде, С. В Азербайджане находится делегация российского пограничного управления / С. Расулзаде // Кавказский узел. - Электрон. текстовые дан. - Режим доступа: http:/www.kavkazuzel.ru/articles/86644/ (дата обращения: 29.09.2016). Загл. с экрана.

23. Расулзаде, С. Россия укрепляет свои границы с Азербайджаном и Грузией / С. Расулзаде // Кавказский узел. - Электрон. текстовые дан. - Режим доступа: http:/www.kavkaz-uzel.ru/ articles/83939/ (дата обращения: 29.09.2016). Загл. с экрана. 
24. Соглашение между Правительством Российской Федерации и Правительством Азербайджанской Республики о пунктах пропуска через государственную границу между Российской Федерацией и Азербайджанской Республикой // Правовой департамент МИД России. - Электрон. текстовые дан. - Режим доступа: http:/www.mid.ru/bdomp/ spd_md.nsf/0/A3BB26BEB8DAD2BF442 57956001D6 BBA (дата обращения: 02.12.2011). - Загл. с экрана.

25. Соглашение между Правительством Российской Федерации и Правительством Азербайджанской Республики о безвизовых поездках граждан Российской Федерации и Азербайджанской Республики // Правовой департамент МИД России. - Электрон. текстовые дан. - Режим доступа: http://www.mid.ru/bdomp/spd md.nsf/0/A66094B 32C94A82344257956001D6AF9 (дата обращения: 02.12.2011). - Загл. с экрана.

26. ФСБ глазами средств массовой информации: граница. Подборка информационных сообщений за январь - август 2006 года // Чекист.ру. - Электрон. текстовые дан. - Режим доступа: http://www. chekist.ru/article/1364 (дата обращения: 4.12.2011). Загл. с экрана.

27. Что еще Россия подарила Азербайджану? / / Федеральная лезгинская национально-культурная автономия. - Электрон. текстовые дан. - Режим доступа: http://flnka.ru/aktualnoe/2501-chto-escherossiya-podarila-azerbaydzhanu.html (дата обращения: 03.10.2016). - Загл. с экрана.

\section{REFERENCES}

1. Azerbaydzhan usilil okhranu granitzy s Rossiey [Azerbaijan Strengthened Border Guard with Russia]. Kavkazskiy uzel. Available at: http://www. kavkaz-uzel.ru/articles/70768/. (accessed May 13, 2016).

2. Azerbaydzhan, RF i Iran podpisali ryad dokumentov $\mathrm{v}$ ramkakh sozdaniya transportnogo koridora Sever-Yug [Azerbaijan, Russian Federation and Iran Signed a Number of Agreements on Developing North-South Transport Corridor]. Kavkazskiy uzel. Available at: http://www.kavkazuzel.ru/articles/180744/. (accessed May 13, 2016).

3. Aliev prosit Eltsina ne vvodit vizovyy rezhim [Aliev Asks Eltsin not to Introduce a Visa Regime]. Nezavisimaya gazeta. Available at: http://www.ng.ru/ cis/1999-11-19/5 aliev.html. (accessed September 28, 2016).

4. Batyev B. Sem krugov ada na rossiiskoazerbaydhzanskoy granitse [Seven Circles of Hell at the Russian-Azerbaijan Borderline]. Vesti.az. Available at: http://www.vesti.az/news/46640. (accessed October 3, 2016).
5. V Dagestane sdany eshche dve zastavy [Two More Border Posts Are Put into Service in Dagestan]. Kunak Inform. Available at: http://ikunak.ru/news/ 2006/10/11/22338. (accessed September 28, 2016).

6. V stolknoveniyakh s narkokontrabandistami pogiblo 7, raneno 9 pogranichnikov [7 Border Guards Died and 9 Were Injured in Confrontation with Drug Dealers]. Novosti-Azerbaydzhan. Available at: http:// www.newsazerbaijan.ru/obsh/20111124/ 6622694.html. (accessed September 28, 2016).

7. Voprosy sozdaniya punktov propuska na rossiyskoy granitse obsudili v Narodnom Sobranii [People Council Discussed the Construction of New Border Posts at the Russian Borderline]. Respublikanskoe informatsionnoe agentstvo [Republican Information Agency]. Available at: http:/ /www.riadagestan.ru/mobile/news/politics/ voprosy_sozdaniya_punktov_propuska_na_rossiyskoy_ granitse_obsudili_v_narodnom_sobranii/. (accessed September 28, 2016).

8. Vstupayut $\mathrm{v}$ silu novye pravila vyezda $\mathrm{v}$ stranu na avtomobilyakh [New Rules of Entrance to a Country by Car Are Coming into Effect]. Disput.az. Available at: http://www.disput.az/index.php?app= forums\&module=forums\&controller=topic\&id $=637173$. (accessed October 3, 2016).

9. Grazhdanam Rossii v Azerbaydhzane predlozhili vybor: legalizuytes, libo uezzhayte [Russian Citizens in Azerbaijan Must Choose: to Legalize their Visits or to Leave the Country]. Aksakal. Available at: http://aksakal.info/news-cis/19856-grazhdanam-rossiiv-azerbaydzhane-predlozhili-vybor-legalizuytes-libouezzhayte.html. (accessed July 29, 2011).

10. Dvizhenie "Svobodnyy Lezgistan» [Independent Lezgistan Movement]. Available at: http://lezgistan.tv. (accessed October 3, 2016).

11. Ionov O. Zhiteli sela Khrakh-uba provedut v Dagestane novuyu aktsiyu protesta [People from Khrakh-uba Village to Organize a New Protest Action in Dagestan]. Kavkazskiy uzel. Available at: http:// www.kavkaz-uzel.ru/articles/185655/. (accessed October 3, 2016).

12. Ionov O. Rosgranitsa: pogranichnye punkty mezhdu Dagestanom i Azerbaydzhanom budut oborudovany peshekhodnymi dorozhkami [Russian Border: Border Offices at Dagestan-Azerbaijan Border Will Get Sidewalks]. Kavkazskiy uzel. Available at: http://www.kavkaz-uzel.ru/articles/196368/. (accessed October 3, 2016).

13. Kazenin K., Suleymanov M., Alekseev M. Dagestanskie narody Azerbaydzhana. Politika, istoriya, kultura [Dagestan Peoples in Azerbaijan. Politics, History, Culture]. Moscow, Evropa Publ., 2006. Available at: http://www.redov.ru/politika/ dagestanskie_narody_azerbaidzhana_politika_istorija_ kultura/index.php. (accessed September 29, 2016). 
14. Kuda devalis zemli yuzhnoy granitsy Dagestana? [Where Are the Southern Dagestan Lands?]. Federalnaya lezginskaya natsionalnokulturnaya avtonomiya [Federal Lezgin National Cultural Autonomy]. Available at: http://flnka.ru/ digest-analytics/3319-kuda-devalis-zemli-yuzhnoygranicy-dagestana.html. (accessed October 3, 2016).

15. Litvinova T. Natsionalno-kulturnaya avtonomiya kak forma samoopredeleniya $\mathrm{i}$ politicheskogo uchastiya narodov Rossii (na primere lezgin) [National Cultural Autonomy as a Form of SelfDetermination and Political Participation of Russian Peoples (on the Example of the Lezgins)]. Istoricheskie, filosofskie, politicheskie i yuridicheskie nauki, kul'turologiya i iskusstvovedenie. Voprosy teorii $i$ praktiki, 2012, no. 7 (21): in 3 parts. Part 3, pp. 115-118.

16. Medzhid F.V Azerbaydzhane vyyavlena krupnaya partiya kontrabandy [Large Contraband Party Is Arrested in Azerbaijan]. Kavkazskiy uzel. Available at: http://www.kavkaz-uzel.ru/articles/ 159584/. (accessed October 3, 2016).

17. Medzhid F. Pogranichniki Azerbaydzhana i Rossii prodolzhat vzaimodeystvie [Border Guards of Azerbaijan and Russia Continue Their Cooperation]. Kavkazskiy uzel. Available at: http://www.kavkazuzel.ru/articles/144745/. (accessed October 3, 2016).

18. Miting khrakhtsev: «Khrakh-Uba - territoriya Rossii» [Meeting in Krakh-uba: Khrakh-uba - is a Russian Area]. Dvizhenie «Svobodnyy Lezgistan» [Independent Lezgistan Movement]. Available at: http://www.lnka72.ru/Newsm/758-Miting-khrakhcev1-KHrakh-uba-territoriya-Rossiir. (accessed October 3, 2016).

19. Na granitse Azerbaydzhana s Rossiey zaderzhany dvoe, pytavshikhsya perevezti v Rossiyu geroin [Two Men Trying to Bring Heroin to Russia Were Captured Close to the Russian-Azerbaijan Border]. Kavkazskiy uzel. Available at: http://www.kavkazuzel.ru/articles/80891/. (accessed October 3, 2016).

20. Parubochaya E. Sotrudnichestvo Turtsii i Azerbaydzhana v voennoy sfere na rubezhe XX-XXI vekov [The Cooperation of Turkey and Azerbaijan in Military Sphere at the Turn of 20th-21st Centuries]. Vestnik Volgogradskogo gosudarstvennogo universiteta. Seriya 4, Istoriya. Regionovedenie. Mezhdunarodnye otnosheniya [Science Journal of Volgograd State University. History. Area Studies. International Relations], 2015, no. 6(36), pp. 24-37.

21. Peresechenie na avtomobile granitsy Azerbaydzhan-Rossiya [Crossing the Azerbaijan-
Russian Border by Car]. Forum Woman-az.ru. Available at: http://woman-az.ru/viewtopic.php?t=360. (accessed September 29, 2016).

22. Rasulzade C.V Azerbaidzhane nakhoditsya delegatsiya rossiyskogo pogranichnogo upravleniya [A delegation of a Russian border department is in Azerbaijan]. Kavkazskiy uzel. 15.12.2005. Available at: http://www.kavkaz-uzel.ru/articles/86644/ (accessed September 29, 2016).

23. Rasulzade C. Rossiya ukreplyaet svoi granitsy s Azerbaydzhanom i Gruziey [Russia Enforces Its Borders with Azerbaijan and Georgia]. Kavkazskiy uzel. Available at: http://www.kavkaz-uzel.ru/articles/ 83939/. (accessed September 29, 2016).

24. Soglashenie mezhdu Pravitelstvom Rossiyskoy Federatsii i Pravitelstvom Azerbaydzhanskoy Respubliki o punktakh propuska cherez gosudarstvennuyu granitsu mezhdu Rossiyskoy Federatsiey i Azerbaydzhanskoy Respublikoy [A Treaty between the Government of the Russian Federation and the Government of Azerbaijan Republic on Border Posts between the Russian Federation and Azerbaijan]. Pravovoy departament MID Rossii [Law Department, Ministry of Foreign Affairs, Russia]. Available at: http://www.mid.ru/ bdomp/spd_md.nsf/0/A3BB26BEB8 DAD2BF44 257956001D6BBA. (accessed December 2, 2011).

25. Soglashenie mezhdu Pravitelstvom Rossiyskoy Federatsii i Pravitelstvom Azerbaydzhanskoy Respubliki o bezvizovykh poezdkakh grazhdan Rossiyskoy Federatsii i Azerbaydzhanskoy Respubliki [A Treaty between the Government of the Russian Federation and the Government of Azerbaijan Republic on Bilateral Visa Free Regime]. Pravovoy departament MID Rossii [Law Department, Ministry of Foreign Affairs, Russia]. Available at: http://www.mid.ru/bdomp/spd_md.nsf/0/ A66094B32C94A82344257956001D6AF9. (accessed December 2, 2011).

26. FSB glazami sredstv massovoy informatsii: granitsa. Podborka informatsionnykh soobshcheniy za yanvar - avgust 2006 goda [FSS through Mass Media: Border. News Collected from January to August 2006]. Chekist.ru. Available at: http://www.chekist.ru/ article/1364. (accessed December 4, 2011).

27. Chto eshche Rossiya podarila Azerbaydzhanu? [What Else Did Russia Give to Azerbaijan?]. Federalnaya lezginskaya natsionalno-kulturnaya avtonomiya [Federal Lezgin National Cultural Autonomy]. Available at: http://flnka.ru/aktualnoe/2501chto-esche-rossiya-podarila-azerbaydzhanu.html. (accessed October 3, 2016). 


\section{Information about the Author}

Ekaterina V. Arkhipova, Candidate of Sciences (History), Associate Professor, Department of International Relations, Political Science and Area Studies, Volgograd State University, Prosp. Universitetsky, 100, 400062 Volgograd, Russian Federation, arkhipova@volsu.ru, http://orcid.org/00000003-1891-5586.

\section{Информация об авторе}

Екатерина Владимировна Архипова, кандидат исторических наук, доцент кафедры международных отношений, политологии и регионоведения, Волгоградский государственный университет, просп. Университетский, 100, 400062 г. Волгоград, Российская Федерация, arkhipova@volsu.ru, http://orcid.org/0000-0003-1891-5586. 